\title{
Pemodelan Perhitungan IndeksLost of Load Probability untuk N Unit Pembangkit pada Sistem Kelistrikan Opsi Nuklir
}

\author{
Rizki Firmansyah Setya Budi,Moch. Djoko Birmano, Imam Bastori \\ Pusat Kajian Sistem Energi Nuklir (PKSEN) - BATAN \\ Jl. Kuningan Barat Mampang Prapatan, Jakarta Selatan, 12710, Indonesia
}

\begin{tabular}{l}
\hline INFORMASI ARTIKEL \\
\hline Riwayat Artikel: \\
Diterima: \\
3 Januari 2018 \\
Diterima dalam bentuk revisi: \\
23 Maret 2018 \\
Disetujui: \\
23 Maret 2016 \\
\end{tabular}

Kata kunci:

Pemodelan

Lost of load probability

Sistem kelistrikan opsi nuklir

\begin{abstract}
ABSTRAK
PEMODELAN PERHITUNGAN INDEKS LOST OF LOAD PROBABILITY UNTUK N UNIT PEMBANGKIT PADA SISTEM KELISTRIKAN OPSI NUKLIR. Perhitungan LOLP dapat dilakukan secara manual ataupun dengan bantuan program. Perhitungan secara manual membutuhkan waktu yang lebih lama dan ketelitian dibandingkan dengan menggunakan bantuan program. Tujuan penelitian ini adalah untuk membuat sebuah model perhitungan indeks LOLP yang lebih sederhana, fleksibel (dapat digunakan untuk $\mathrm{N}$ jumlah pembangkit), dan waktu perhitungan yang lebih cepat. Program perhitungan LOLP menggunakan bantuan program Matlab. Penelitian dilakukan dengan langkah sebagai berikut: pembuatan source code pada Matlab, perhitungan indeks LOLP dengan data masukkan yang digunakan, dan validasi hasil perhitungan. Validasi dilakukan dengan cara bencmarking terhadap hasil perhitungan penelitian sebelumnya. Hasil penelitian menunjukkan bahwa model perhitungan indeks LOLP untuk $N$ unit pembangkit pada sistem kelistrikan opsi nuklir telah berhasil dibuat dengan mempertimbangkan aspek kesederhanaan data masukkan, fleksibilitas, dan waktu yang lebih cepat. Hasil perhitungan dapat dinyatakan valid dengan selisih yang kurang dari $1 \%$ jika dibandingkan dengan hasil pada penelitian sebelumnya yang telah menghitung indeks LOLP dengan cara manual.

Kata kunci:pemodelan, lost of load probability, sistem kelistrikan opsi nuklir
\end{abstract}

\begin{abstract}
MODELING OF LOST OF LOAD PROBABILITY INDEX CALCULATION FOR N UNIT POWER PLANTSINNUCLEAR OPTION POWER SISTEMS. LOLP calculations can be done manually or using a program. Manual calculations take longer time and need more effort than using the program. The purpose of this research is to make a simple LOLP calculation model, flexible (can be used for $\mathrm{N}$ number of power plants), and faster calculation time. LOLP calculation program uses Matlab program. The research is done with the following steps: making source code in Matlab, calculation of LOLP with an input data, and result validation. Validation is done by bencmarking to previous research calculations. The results show that the LOLP index calculation model for $\mathrm{N}$ power plant units in the nuclear option power sistem has been successfully established by considering the simplicity aspects of input data, flexibility, and faster calculation time. The calculation results can be declared valid with a difference of less than $1 \%$ when compared with the results in previous study that has calculated the LOLP index manually. Keywords:modeling, lost of load probability, nuclear option power sistem
\end{abstract}

\section{PENDAHULUAN}

Indeks keandalan menunjukkan kualitas dan kemampuan sebuah sistem kelistrikan. Indeks keandalan yang digunakan oleh PT. Perusahaan Listrik Negara (PLN) dalam perencanaan sistem kelistrikan adalah lost of load probability (LOLP) dengan nilai kurang dari 0,274\%. LOLP adalah kemungkinan sistem tidak dapat memasok energi listrik ke pelanggan. LOLP kurang dari 0,274\% berarti sistem hanya diperbolehkan tidak dapat memasok energi listrik ke pelanggan maksimal 1 hari/tahun [1-5].

*Penuliskorespondensi.

E-mail: rizkifirmansyah@batan.go.id
Nilai LOLP dipengaruhi oleh kurva beban harian, laju kegagalan paksa (forced outage rate $=$ FOR $)$ pembangkit, jumlah dan kapasitas unit pembangkit. Laju kegagalan terdiri dari 2 macam: laju kegagalan paksa dan laju kegagalan yang dijadwalkan (scheduled outage rate $=\mathrm{SOR}$ ). FOR adalah kegagalan pembangkit yang disebabkan karena sesuatu hal yang tidak direncanakan sedangkan SOR adalah kegagalan pembangkit yang disebabkan karena sesuatu yang telah dijadwalkan seperti pemeliharaan pembangkit. Perhitungan LOLP menggunakan FOR karena peninjauan 
keandalan dilakukan selama selang waktu pada saat pembangkit tidak menjalani pemeliharaan terjadwal [6-9].

Perhitungan LOLP dapat dilakukan secara manual ataupun dengan bantuan program. Perhitungan secara manual membutuhkan waktu yang lebih lama dan ketelitian dibandingkan dengan menggunakan bantuan program. Beberapa penelitian telah melakukan perhitungan LOLP menggunakan program WASP IV, Microsoft Excel, dan Matrix laboratory (Matlab) [10-16].

Pada penelitian $[10,14]$ telah dilakukan perencanaan pengembangan sistem kelistrikan dan perhitungan indeks LOLP dengan program WASP IV. Program ini digunakan untuk melakukan perencanaan pengembangan sistem kelistrikan sehingga membutuhkan data teknis dan ekonomi pembangkit, kurva beban, dan pertumbuhan beban. Dengan kata lain, jika program WASP IV hanya digunakan untuk perhitungan indeks LOLP maka pengguna harus memasukkan data-data yang sebenarnya tidak diperlukan dalam proses perhitungan indeks LOLP. Sedangkan kelebihan penggunaan WASP IV untuk perhitungan indeks LOLP adalah dapat digunakan untuk berbagai macam kondisi dan jumlah komposisi pembangkit.

Pada penelitian [11], [15], dan [16] telah dilakukan perhitungan indeks LOLP menggunakan program Microsoft Excel. Pada penelitian ini, pengguna hanya diharuskan memasukkan data yang dibutuhkan saja karena program yang dibuat dalam Microsoft Excel ini hanya dikhususkan untuk menghitung indeks LOLP. Kekurangan dalam menggunakan Microsoft Excel adalah meningkatnya resiko kesalahan akibat proses perhitungan yang masih manual dan membutuhkan waktu yang lebih lama. Hal ini disebabkan karena pengguna harus melakukan 3 langkah secara manual, yaitu memasukkan data, pembentukan matriks kombinasi pembangkit dan mengurutkan data secaras ekaligus.

Pada penelitian [12] dan [13] telah dilakukan perhitungan indeks LOLP menggunakan program Matlab. Perhitungan menggunakan Matlab mempunyai keunggulan dalam segi waktu dan data yang dibutuhkan hanya mencakup FOR, kapasitas pembangkit, jumlah pembangkit dan kurva beban. Sedangkan kekurangan penggunaan Matlab pada penelitian [12] dan [13] adalah hanya bisa digunakan pada jumlah pembangkit dan kondisi kurva beban tertentu saja.

Berdasarkan penelitian diatas dapat diperoleh informasi bahwa setiap program perhitungan mempunyai kelemahan dan kelebihan masing-masing. Tujuan penelitian ini adalah untuk membuat sebuah model perhitungan indeks LOLP yang sederhana (data yang dibutuhkan lebih sedikit jika dibandingkan dengan program WASP IV), fleksibel (dapat digunakan untuk $\mathrm{N}$ jumlah pembangkit), dan waktu perhitungan yang lebih cepat. Penelitian ini akan menggabungkan kelebihan dari penelitian [1016] untuk dapat mewujudkan tujuan tersebut. Perbedaan pemodelan pada penelitian ini dengan penelitian [12] dan [13] adalah jika program perhitungan pada penelitian [12] dan [13] hanya dapat digunakan pada jumlah pembangkit dan kondisi kurva beban tertentu saja, program pada penelitian ini dapat digunakan untuk berbagai macam jumlah pembangkit dan kondisi kurva beban yang berbeda-beda.

Program perhitungan LOLP menggunakan program Matlab. Program Matlab digunakan untuk melakukan pembuatan source code perhitungan dan melakukan iterasi perhitungan tersebut. Kelebihan penggunaan Matlab dalam penelitian ini adalah Matlab dapat mengatasi kekurangan yang ada ketika melakukan perhitungan menggunakan Excel sehingga pengguna hanya cukup melakukan input data secara manual dan setelah itu semua proses akan dilakukan secara otomatis didalam Matlab.Validasi hasil perhitungan dengan program ini dilakukan dengan cara membandingkan hasil dengan hasil penelitian [11]. Penelitian [11] telah melakukan perhitungan indeks LOLP untuk sistem kelistrikan dengan opsi nuklir.

\section{DASAR TEORI}

\subsection{Perhitungan Indeks LOLP}

Indeks LOLP dihitung dengan menjumlahkan lama waktu beban tidak terlayani pada semua kemungkinan pada kurun waktu tertentu. Indeks LOLP dapat dihitung 
dengan menggunakan $1[11,17,18,19]$.

\section{LOLP $=\sum_{i=0}^{n} P_{t} t_{t}$}

Keterangan:

$\mathrm{P}=$ Probabilitaskumulatif kombinasi

$\mathrm{t}=$ durasikehilanganbeban

$\mathrm{n}=$ jumlah kombinasi

$\mathrm{i}=$ indeks kombinasi

Probabilitas kumulatif diperoleh berdasarkan nilai dari probabilitas individu. Misalkan saja terdapat 3 unit pembangkit 10 MW dengan FOR 10\%. Perhitungan probabilitas kumulatif dapat dihitung berdasarkan pada Tabel 1 [6,11].

Tabel 1. Probabilitas Kumulatif $[6,11]$

\begin{tabular}{cccc}
\hline $\begin{array}{c}\text { Pembangkit } \\
\text { Beroperasi } \\
\text { (MW) }\end{array}$ & $\begin{array}{c}\text { Pembangkit } \\
\text { Tidak } \\
\text { Beroperasi } \\
\text { (MW) }\end{array}$ & $\begin{array}{c}\text { Probabilitas } \\
\text { Individu }\end{array}$ & $\begin{array}{c}\text { Probabilitas } \\
\text { Kumulatif }\end{array}$ \\
\hline 30 & 0 & 0,729 & 1 \\
20 & 10 & 0,243 & 0,271 \\
10 & 20 & 0,027 & 0,028 \\
0 & 30 & 0,001 & 0,001 \\
\hline
\end{tabular}

Durasi kehilangan beban diperoleh dengan menggabungkan antara kapasitas pembangkit, probabilitas kumulatif dan load duration curve (LDC). Gambar 1 menunjukkan penggabungan kapasitas pembangkit, probabilitas kumulatif, dan $\operatorname{LDC}[6,11]$.

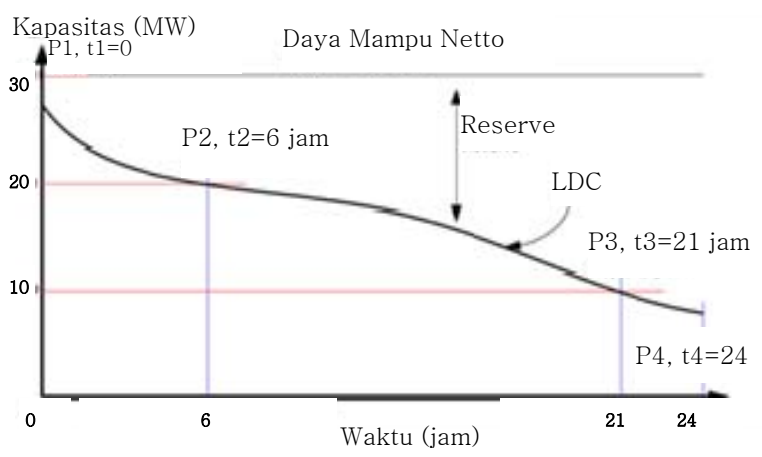

Gambar 1. Penggabungan LDC dengan Probabilitas Kumulatif[6,11]

Pada saat kapasitas pembangkit beroperasi sebesar 30 MW, kurva LDC terpotong di titik 0 jam. Kapasitas pembangkit beroperasi sebesar 30 MW memiliki probabilitas kumulatif 1. Pada saat kapasitas pembangkit beroperasi dengan daya 20 MW, kurva LDC terpotong di titik 6 jam. Kapasitas pembangkit beroperasi sebesar 20 MW memiliki probabilitas kumulatif 0,271. Pada saat kapasitas pembangkit beroperasi sebesar 10 MW, kurva LDC terpotong di titik 21 jam. Kapasitas pembangkit beroperasi sebesar 10 MW memiliki probabilitas kumulatif 0,028. Pada saat kapasitas pembangkit beroperasi sebesar 0 MW, kurva LDC terpotong di titik 24 jam. Kapasitas pembangkit beroperasi sebesar 0 MW memiliki probabilitas kumulatif 0,001[6,11]. Berdasarkan persamaan 1 dan data-data di atas, maka dapat diperolehindeks LOLP $=(1 \times 0)+(0,271 \times 6)+(0,028 \times 21)+$ $(0,001 \times 24)=2,238 \mathrm{jam} /$ hari $[6,11]$.

Perhitunganindeks LOLP di atasakan membutuhkan waktu cukup lama jika dilakukan secara manual dengan bantuan program Microsoft Excel. Waktu yang dibutuhkan berbanding lurus dengan jumlah pembangkit. Selain itu, resiko lain yang dapat muncul adalah kesalahan perhitung akibat ketidaktelitian manusia.Permasalahan tersebut dapat diatasi dengan pemodelan perhitungan dengan bantuan program Matlab.

\subsection{Implementasi Program Matlab dalam Perhitungan Indeks LOLP}

Program Matlab adalah program yang telah diterima oleh komunitas akademik internasional sebagai standar untuk program komputasi. Program Matlab dapat digunakan untuk memproses data dengan jumlah yang besar secara efisien. Selain itu Program Matlab dapat melakukan komputasi matriks dengan mudah [20-22]. Kemampuan untuk menghitung matriks dan data dalam jumlah besar sangat sesuai untuk menghitung indeks LOLP. Fungsi-fungsi penting dalam program Matlab yang digunakan dalam perhitungan indeks LOLP adalah sortrows, polyfit, polyval, binopdf, dan binocdf

Fungsi sortrows digunakan untuk mengurutkan data di dalam matriks baik dari yang tertinggi ke terendah ataupun dari terendah ke tertinggi [23,24]. Fungsi sortrows dalam penelitian ini digunakan untuk membentuk LDC dari data kurva beban dan membentuk kombinasi pembangkit yang diurutkan dari kapasitas terbesar ke terkecil. 
Persamaan 2 menunjukkan fungsi sortrows untuk membentuk LDC [12]. Persamaan 3 menunjukkan fungsi sortrows untuk membentuk kombinasi pembangkit yang telah diurutkan dari yang terbesar ke terkecil [12].

LDC $=$ sortrows $($ kurva_beban, -1$)$;

Mixed= $\operatorname{sortrows}($ mixed, -1$)$;

Fungsi polyfit digunakan untuk mencari koefisien persamaan polinomial dari kumpulan sebuah data $[25,26]$. Sedangkan fungsi polyval digunakan untuk membuat kurva dan persamaan dari koefisien persamaan yang telah diketahui [27]. Fungsi polyfit dalam penelitian ini digunakan untuk mencari koefisien persamaan polinomial dari data LDC yang telah diurutkan dari yang terbesar ke terkecil. Kurva LDC ini digunakan untuk menentukan kemampuan sebuah kombinasi pembangkit untuk menyuplai beban yang ada. Jika kapasitas kombinasi lebih kecil dari beban maka akan terjadi kehilangan beban. Persamaan 4 menunjukkan fungsi dari polyfit[12].

\section{Coef=polyfit $(L D C l o a d, n, 4)$;}

Fungsi binopdf digunakan untuk menghitung individual probability dari setiap kombinasi pembangkit[28]. Sedangkan binocdf digunakan untuk menghitung probabilitas kumulatif dari setiap kombinasi pembangkit [29]. Kedua fungsi ini digunakan untuk membentuk probabilitas individu dan kumulatifseperti pada Tabel 1. Persamaan 5dan 6 menunjukkan fungsi dari binopdf dan binocdf [12].

$\operatorname{Ind}(x, i)=\operatorname{binopdf}((N(i)-x+1), N(i),(1-F O R(i)))$;

$\operatorname{Cum}(x, i)=\operatorname{binocdf}((N(i)-x+1), N(i),(1-F O R(i)))$;

Dengan menggunakan beberapa fungsi diatas, kekurangan dalam menghitung indeks LOLP menggunakan Microsoft Excel dapat diatasi. Program Matlab dapat membentuk matriks kombinasi beserta probabilitas kumulatif yang telah diurutkan secara sekaligus dan dalam jangka waktu yang cepat.

\section{METODOLOGI}

Penelitian ini dilakukan dengan metodologi seperti pada Gambar 2.

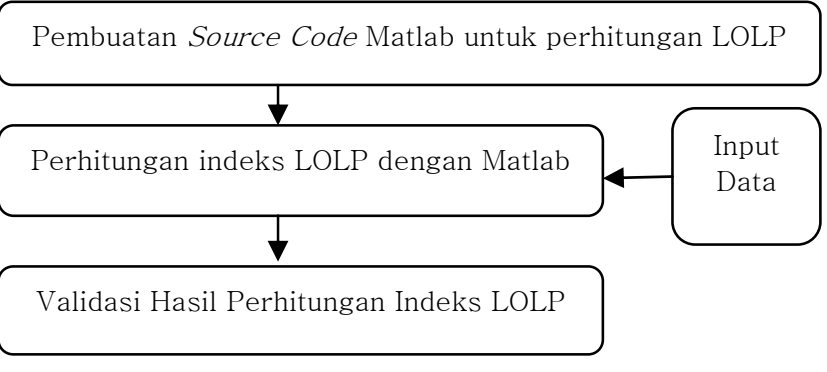

Gambar 2. Flowchart Penelitian

Pembuatan source codeMatlab untuk perhitungan LOLP dilakukan dengan cara seperti pada Gambar 3.

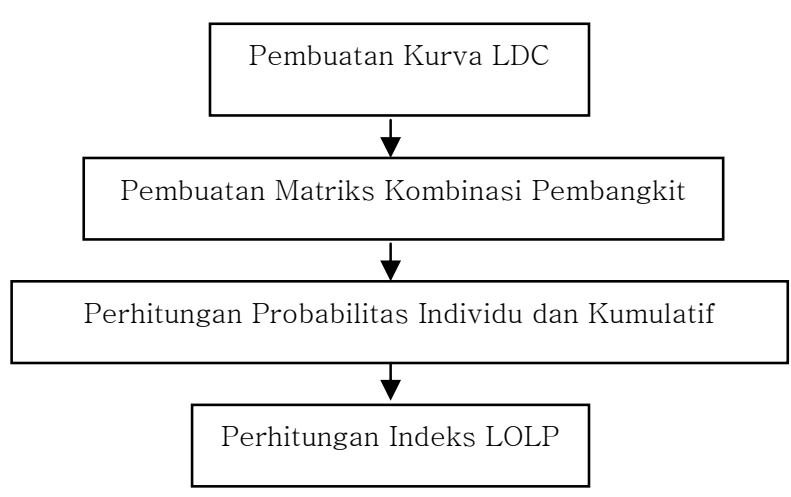

Gambar 3. Flowchart Perhitungan Indeks LOLP dengan Matlab

Kurva LDC dibentuk menggunakan kurva beban harian. Kurva tersebut diurutkan dari yang paling besar menggunakan persamaan 2. Selanjutnya, dilakukan normalisasi terhadap beban puncaknya. Setelah kurva LDC didapatkan, persamaan 4 digunakan untuk mencari koefisien persamaan polinomial dari data LDC. Persamaan ini yang akan digunakan untuk mengetahui titik perpotongan kurva LDC pada saat kapasitas pembangkit tertentu. Titik ini mewakili durasi beban tak terlayani (seperti yang telah dicontohkan pada sub bab 2.1). Pembuatan matriks kombinasi pembangkit dilakukan menggunakan persamaan 3. Setelah matriks kombinasi pembangkit terbentuk, maka dilakukan perhitungan probabilitas individu dan kumulatifdengan menggunakan persamaan 5 dan 6. Langkah terakhir dari flowchart 
program ini adalah perhitungan indeks LOLP menggunakan persamaan 1.

Langkah selanjutnya setelah didapatkan model perhitungan indeks LOLP adalah memasukkan data yang dibutuhkan dalam perhitungan. Data yang dibutuhkan dalam penelitian ini adalah FOR, kapasitas pembangkit, jumlah pembangkit dan kurva beban. Data tersebut diperoleh dari penelitian [11]. Pada penelitian [11] dilakukan perhitungan indeks LOLP secara manual pada sistem kelistrikan Bangka. Terdapat dua skenario pada penelitian tersebut: Skenario RUPTL dan Skenario opsi nuklir. Gambar 4 menunjukkan kurva beban harian. Tabel 2 menunjukkan data pembangkit skenario RUPTL dan Tabel 3 menunjukkan data pembangkit skenario opsi nuklir.

Proses validasi hasil perhitungan indeks LOLP dilakukan dengan perbandingan perhitungan indeks LOLP yang telah dilakukan pada penelitian [11].

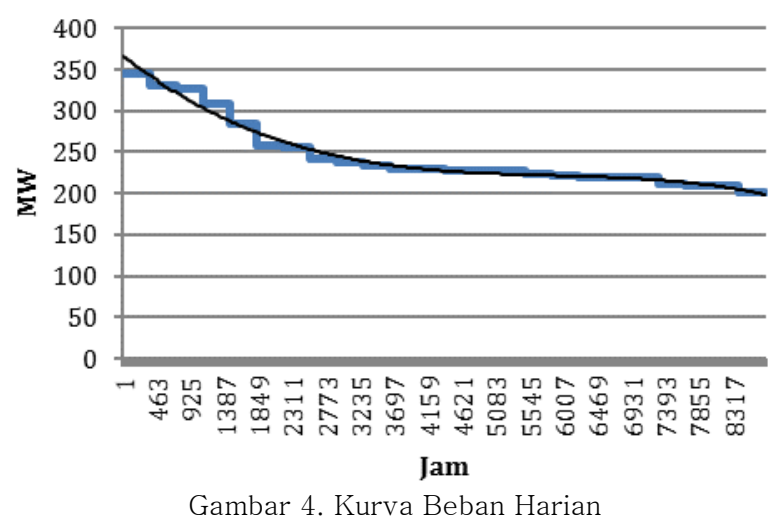

Tabel 2. Data Pembangkit Skenario RUPTL

\begin{tabular}{lccc}
\hline Jenis & Kapasitas & Unit & FOR \\
\hline PLTU & 2,8 & 1 & 0,05 \\
PLTU & 30 & 1 & 0,05 \\
PLTG/MG & 50 & 1 & 0,023 \\
PLTU & 100 & 1 & 0,05 \\
PLTU & 100 & 1 & 0,05 \\
PLTG/MG & 50 & 1 & 0,023 \\
PLTG/MG & 50 & 1 & 0,023 \\
PLTU & 100 & 1 & 0,05 \\
PLTU & 100 & 1 & 0,05 \\
\hline
\end{tabular}

Tabel 3. Data Pembangkit Skenario Opsi Nuklir

\begin{tabular}{lccc}
\hline Jenis & Kapasitas & Unit & FOR \\
\hline PLTU & 2,8 & 1 & 0,05 \\
PLTU & 30 & 1 & 0,05 \\
PLTG/MG & 50 & 1 & 0,023 \\
PLTU & 100 & 1 & 0,05 \\
PLTU & 100 & 1 & 0,05 \\
PLTG/MG & 50 & 1 & 0,023 \\
PLTG/MG & 50 & 1 & 0,023 \\
PLTN & 100 & 1 & 0,015 \\
PLTN & 100 & 1 & 0,015 \\
\hline
\end{tabular}

\section{HASIL DAN PEMBAHASAN}

Berdasarkan hasil perhitungan dengan model yang dibuat pada penelitian ini dan perbandingan dengan hasil pada penelitian [11], diperoleh perbandingan seperti pada Tabel 4.

\begin{tabular}{|c|c|c|c|}
\hline & $\begin{array}{c}\text { Hasil Penelitian } \\
\text { [11] }\end{array}$ & $\begin{array}{c}\text { Hasil } \\
\text { program }\end{array}$ & Deviasi \\
\hline $\begin{array}{l}\text { enario } \\
\text { PTL }\end{array}$ & $0,817 \%$ & $0,814 \%$ & $0,3 \%$ \\
\hline $\begin{array}{l}\text { enario } \\
\text { i nuklir }\end{array}$ & $0,170 \%$ & $0,170 \%$ & $0 \%$ \\
\hline
\end{tabular}

Hasil perhitungan model mempunyai deviasi sebesar 0,3\% dan 0\% jika dibandingkan dengan hasil perhitungan pada penelitian [11]. Selisih yang kurang dari $1 \%$ tersebut menunjukkan bahwa hasil perhitungan indeks LOLP dengan model perhitungan penelitian ini dapat dinyatakan valid.

Selisih tersebut disebabkan karena adanya perbedaan significant unit dalam perhitungan excel dan matlab. Significant unit melambangkan jumlah nilai desimal yang digunakan dalam perhitungan. Sebagai contoh: $3,3 \times 3,3 \times 3,3 \neq 3,33 \times 3,33 \times 3,33$.

Model perhitungan yang dibuat dalam penelitian ini hanya membutuhkan data masukan kurva beban dan data pembangkit. Data pembangkit yang dibutuhkan adalah kapasitas, jumlah unit dan FOR. Dengan kata lain model perhitungan indeks LOLP dalam penelitian memenuhi tujuan penelitian yaitu membuat model perhitungan yang sederhana. Data masukkan yang dibutuhkan dalam 
perhitungan lebih sedikit jika dibandingkan dengan data masukkan pada penelitian [10]. Penelitian [10] menghitung indeks LOLP dengan program WASP IV sehingga data yang diperlukan bukan hanya data untuk perhitungan indeks LOLP saja tetapi juga data untuk perencanaan sistem kelistrikan. Prinsip kesederhanaan data ini mengambil kelebihan dari metode perhitungan indeks LOLP secara manual yang telah dilakukan pada penelitian [11].

Jumlah pembangkit dapat diubah-ubah dengan cara mengubah nilai unit dan atau mengubah jumlah jenis pembangkit. Hal tersebut sesuai dengan tujuan penelitian: membuat model perhitungan indeks LOLP yang dapat digunakan $\mathrm{N}$ unit pembangkit. Jumlah pembangkit tersebut akan berpengaruh terhadap waktu perhitungan. Hal tersebut disebabkan karena jika jumlah pembangkit bertambah maka jumlah kombinasi pembangkit yang digunakan dalam perhitungan akan bertambah. Dengan kata lain akan ada pertambahan ukuran matriks kombinasi pembangkit sehingga menyebabkan waktu iterasi bertambah. Begitu juga sebaliknya jika jumlah pembangkit berkurang. Hal ini selaras dengan hasil penelitian [30] dan [31] yang menyebutkan bertambahnya ukuran matriks kombinasi pembangkit menyebabkan bertambahnya waktu perhitungan.

Tujuan terakhir dari pembuatan model perhitungan ini adalah membuat model perhitungan yang dapat mempercepat waktu perhitungan jika dibandingkan dengan perhitungan dengan Excel. Tabel 5 menunjukkan perbandingan waktu perhitungan antara model perhitungan dengan perhitungan menggunakan Excel.

Tabel 5. Perbandingan Waktu Perhitungan

\begin{tabular}{lcc}
\hline & \multicolumn{2}{c}{ Waktu perhitungan } \\
\cline { 2 - 3 } & $\begin{array}{c}\text { Perhitungan } \\
\text { Excel }\end{array}$ & $\begin{array}{c}\text { Perhitungan } \\
\text { dengan model } \\
\text { perhitungan }\end{array}$ \\
\hline RUPTL & 2700 detik & 3,9 detik \\
Opsi Nuklir & 2850 detik & 4,2 detik \\
\hline
\end{tabular}

Waktu perhitungan pada model ini akan membuat waktu perhitungan sangat jauh berkurang. Hal tersebut disebabkan karena semua perhitungan akan dilakukan secara otomatis di dalam model, tidak ada lagi perhitungan secara manual. Waktu perhitungan menggunakan Excel seperti yang dilakukan pada penelitian [11] akan sangat bergantung pada kecepatan pengguna dalam melakukan perhitungan dan jumlah pembangkit. Sedangkan waktu perhitungan dalam model perhitungan ini dipengaruhi jumlah pembangkit, spesifikasi komputer dan kondisi komputer pada saat menjalankan program.

Gambar 5 menunjukkan komposisi waktu perhitungan dengan menggunakan program. Pada kedua skenario yang digunakan menunjukkan waktu yang hampir sama. Hal tersebut disebabkan karena jumlah pembangkit nya sama. Hal tersebut juga menyebabkan komposisi waktu perhitungan yang hampir sama. Pada kedua skenario tersebut, $47 \%$ waktu perhitungan digunakan untuk proses pembentukan LDC, $16 \%$ digunakan untuk membuat matriks kombinasi dan capacity outage probability table (COPT), dan 37\% digunakan untuk perhitungan LOLP. Waktu yang digunakan untuk membentuk LDC lebih besar jika dibandingkan yang lain karena data beban harian yang digunakan sebanyak 8760 buah sedangkan jumlah pembangkit yang digunakan adalah 9 pembangkit. Dengan 9 pembangkit, kombinasi yang dimungkinkan adalah 512 kombinasi (2^9). Perbedaan jumlah data tersebut akan berpengaruh terhadap waktu yang dibutuhkan pada masing-masing proses. Semakin banyak data akan menyebabkan semakin lama waktu yang dibutuhkan.

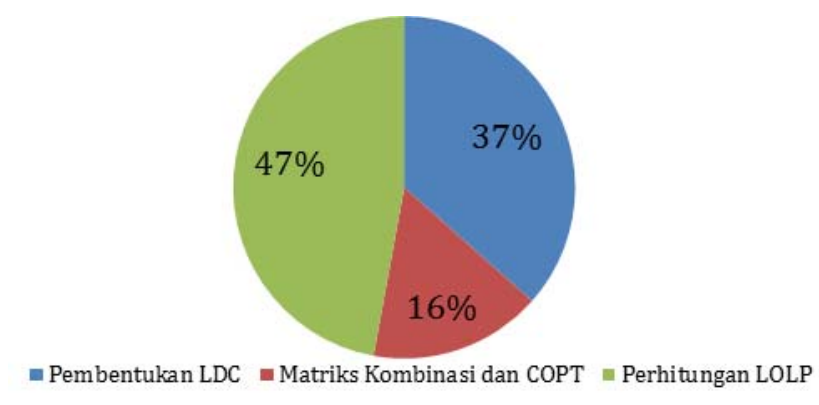

Gambar 5. Komposisi Waktu Perhitungan dengan Program

Komposisi tersebut akan berubah jika jumlah pembangkit yang digunakan bertambah. Jumlah data beban harian yang digunakan merupakan jumlah yang tetap tidak berubah untuk berbagai macam sistem kelistrikan. Hal tersebut menyebabkan jika jumlah pembangkit meningkat dan jumlah data beban tetap, maka akan menurunkan porsi waktu pembentukan 
LDC, meningkatkan porsi waktu matriks kombinasi dan COPT, dan meningkatkan porsi waktu perhitungan LOLP. Gambar 6 menunjukkan perbedaan porsi pembentukan LDC, matriks kombinasi dan COPT, dan perhitungan LOLP pada setiap jumlah pembangkit. Seperti yang telah dibahas sebelumnya, penambahan jumlah unit pembangkit akan menurunkan porsi waktu pembentukan LDC, meningkatkan porsi waktu matriks kombinasi dan COPT, dan meningkatkan porsi waktu perhitungan LOLP.

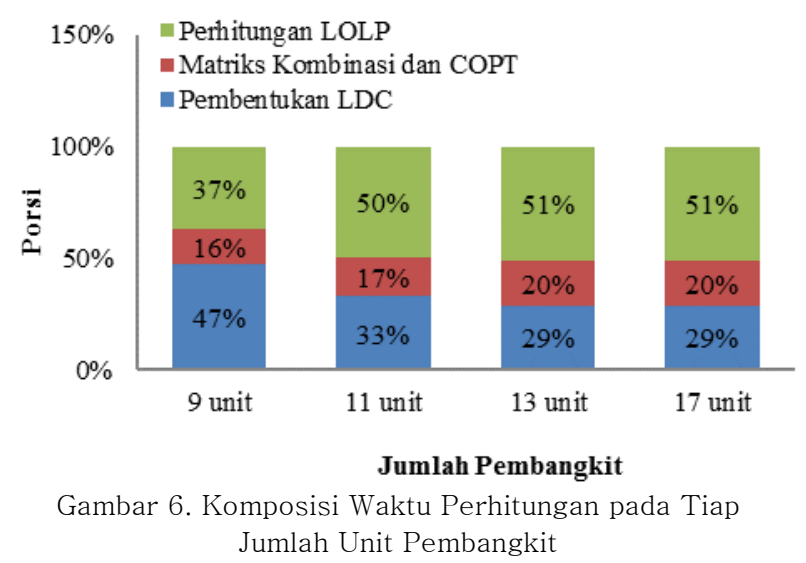

\section{KESIMPULAN}

Model perhitungan indeks LOLP untuk N unit pembangkit pada sistem kelistrikan opsi nuklir telah berhasil dibuat dengan mempertimbangkan aspek kesederhanaan data masukkan, flesibilitas, dan waktu yang lebih cepat. Hasil perhitungan dapat dinyatakan valid dengan selisih yang kurang dari $1 \%$ jika dibandingkan dengan hasil pada penelitian sebelumnya.

\section{UCAPAN TERIMA KASIH}

Terima kasih diucapkan kepada Dr. Eka Firmansyah atas sarannya selama mata kuliah metode penelitian dan BATAN atas beasiswa yang telah diberikan.

\section{DAFTAR ACUAN}

[1]. Wirapraja, A. Y., dkk, "Studi Analisis Keandalan Sistem Distribusi Tenaga Listrik Surabaya menggunakan Metode Latin Hypercube Sampling",
Jurnal Teknik POMITS Vol. 1 No. 1, 2012, Hal. 15.

[2]. Kim, Hyungchul,"Evaluation of Power Sistem Security and Development of Transmission Price Method”, Dissertation Texas A\&M University, 2003.

[3]. Pottonen, Liisa, "A Method for The Probabilistic Security Analysis of Transmission Grid”, Doctoral Dissertation, Helsinki University of Technology, 2005.

[4]. Yeu, Rodney, "Post-Contingency Equilibrium Analysis", IEEE Toronto Centennial Forum on Reliable Power Grids in Canada, 2005.

[5]. Hartoyo, "Perbaikan Keandalan (N-1) Sistem Tenaga Listrik PLN Jawa Tengah dan DIY", Fakultas Teknik Universitas Negeri Yogyakarta. Yogyakarta, 2008.

[6]. Zein, Hermagasantos, "Perkiraaan Pasokan Daya Sistem Jawa-Madura-Bali sampai Tahun 2016 berdasarkan Indeks LOLP Satu Hari per Tahun”, Transmisi-Jurnal Teknik Elektro Jilid 10 No. 1, 2008, hlm 6-9.

[7]. Prawira, "Studi Sekuriti Sistem Ketersediaan Daya DKI Jakarta dan Tangerang 2007 -2016”, Skripsi Program Studi Teknik Elektro ITB, 2008.

[8]. Sapkota, Deepak, Et. Al., "Reliability and Availability Evaluation of Sunkoshi Hydro Power Station", Proceedings of IOE Graduate Conference, 2014, pp. $197-202$.

[9]. Sahu, M.,Barve, A., "Reliability and Availability Evaluation of Hydro Power Station”, International Journal on Emerging Technologies 4 (2), 2013, pp. $89-93$.

[10]. Budi, R. F. S., Suparman, "Studi Perencanaan Pengembangan Pembangkit Wilayah Bangka Belitung Dengan Opsi Nuklir”, Prosiding Seminar Nasional Pengembangan Energi Nuklir 2011, 2011.

[11]. Budi, R. F. S., dkk., "Peran PLTN dalam Meningkatkan Indeks Keandalan Lost Of Load Probability (LOLP) Sistem Kelistrikan Bangka”, Seminar Nasional SDMTN 2015, 2015.

[12]. Shabanzadeh, M., Heldarizadeh, M., "Power Sistem Reliability Indices Calculation (such as LOLP and EENS) Using MATLAB”, ResearchGate: Dataset January 2008.

[13]. Sinha, Anubhav, "A Power Sistem Reliability Evaluation Technique and Education Tool for Wind Energi Integration", Thesis of Arizona State University, May 2012.

[14]. Shinwari, F., Et Al., "Modeling of Existing and Candidate Hydro Power Plants Generation Expansion Planning using Wien Automatic Sistem Planning IV Model", Journal of Basic and Applied Scientific Research 3 (120), 2013, pp. 119-133.

[15]. Phoon H. Y., "Generation Sistem Reliability Evaluations with Intermittent Renewables, Thesis for the M.Sc in Energi Sistems and the Environment”, University of Strathclyde, Glasgow, UK. 2006.

[16]. Abdelkarim, A. A., Et al.,"Generation Reliability Analysis For The Forecasted Scenarios of Sudan National Grid", Sudan Engineering Society Journal, Vol. 57 No. 1, 2011, pp. 55-68.

[17]. Guziel, Karen,"Probabilistic Simulation”, Center for Energi, Environmental, and Economic Sistems Analysis (CEEESA), USA, 2002. 
[18]. Solichan, Ahcmad, dkk., "Optimasi Jadwal Operasi dan Pemeliharaan Pembangkit Tenaga Listrik menggunakan Metode Algoritma Genetik", Simposium Nasional Teknologi Terapan (SNTT) 2013, 2013.

[19]. Yawantoro, Eri, Dkk., "Analisa Keandalan Sistem Tenaga Listrik Jawa Tengah dan DIY Periode Tahun 2009 - 2011”, Jurnal Media Elektrika, Vol. 5 No. 1, Juni 2012, Hal. 1 - 14.

[20]. Zeng, Liang, Et Al., "Implementation of Multigrid Solver on a GPU for Stokes Equations with Strongly Variable Viscosity based on Matlab and CUDA", The International Journal of High Performance Computing Applications Vol. 28(I), 2014,pp. 50-60.

[21]. Feng, Gao, "Applications of Matlab in Mathematical Analyis", Journal of Software Vol. 6 No. 7, 2011, pp. 1225-1229.

[22]. Cui, Jei, Et Al., "BSMART: A Matlab/C Toolbox for Analysis of Multichannel Neural Time Series”,Neural Network 21, 2008, pp. 1094-1104.

[23]. Souza, J.D.,Rostirolla, S.P., “A Fast Matlab Program to Estimate The Multifractal Spectrum of Multidimensional Data: Application to Fractures”, Computers \& Geosciences 37, 2011,pp. 241-249.

[24]. Nikolova, M.,Steidl, G.,"Fast Ordering Algorithm for Exact Histogram Specifiaction", IEEE Trans Image Process 23(12), 2014, pp. 5274-83.

[25]. Wang, Xiaowei, Et Al.,"Simulation of Direct Current Sensor Based on Magnetic Potential SelfBalance and Feedback Compensation”, IEEE 2004 Conference on Precision Electromagnetic Measurements Digest London, pp. 630-631.

[26]. Berthe, K..A., Et Al.,"Gumbel Weibull Distribution Function for Sahel Precipitation Modeling and Predicting: Case of Mali”, African Journal of
Environmental Science and Technology Vol. 9(55), pp. 405-412.

[27]. Fadili, A. E., Et Al.,"Reference Voltage Optimizer for Maximum Power Tracking in Single-Phase Grid-Connected Photovoltaic Sistems", Journal of Control and Sistems Engineering Vol. 1 Iss. 2, 2013, pp. 57-66.

[28]. Freire, Valdinei, Et Al.,"Evaluation of Linear Relaxations in Ad Network Optimization for Online Marketing", Journal of the Brazilian Computer Society, 2015, pp. 21:13

[29]. Ko, A. L., Et Al.,"Quasi-periodic Fluctuations in Default Mode Network Electrophysiology", The Journal of Neuroscience 31(32), 2011, pp. 1172811732.

[30]. A, Kumar, Et Al., "Capacity Outage Probability Table Calculation (COPT) of Haryana Power Generation Corporation Limited using VBA", Int. J. Tech. Res. Vol.2 No.2, 2013, pp. 6-11.

[31]. R. C. G. II, L. Wang, Et Al., "An Examination of Artificial Immune Sistem Optimization in Intelligent State Space Pruning for LOLP Estimation”, North American Power Symposium (NAPS), 2011, pp. 17. 